\title{
DeVELOPMENTAL MORPHOLOGY OF BUD GALLS INDUCED ON THE VEGETATIVE MERISTEMS OF QUERCUS CASTANEA BY AMPHIBOLIPS MICHOACAENSIS (HYMENOPTERA: CYNIPIDAE)
}

\author{
Paulina Hernández-Soto ${ }^{1,4,6}$, Miguel Lara-Flores², Lourdes Agredano-Moreno 3 , \\ luis Felipe Jiménez-García ${ }^{3}$, Pablo Cuevas-Reyes ${ }^{5}$ and Ken Oyama ${ }^{1,4}$ \\ 'Instituto de Investigaciones en Ecosistemas y Sustentabilidad, Universidad Nacional Autónoma de México. \\ Morelia, Michoacán, México. \\ ${ }^{2}$ Escuela Nacional de Estudios Superiores Unidad León, Universidad Nacional Autónoma de México. \\ León, Guanajuato, México. \\ ${ }^{3}$ Departamento de Biología Celular, Facultad de Ciencias, Universidad Nacional Autónoma de México. México, D.F. \\ ${ }^{4}$ Escuela Nacional de Estudios Superiores Unidad Morelia, Universidad Nacional Autónoma de México. \\ Morelia, Michoacán, México. \\ ${ }^{5}$ Facultad de Biología, Universidad Michoacana de San Nicolás de Hidalgo. Morelia, Michoacán, México. \\ ${ }^{6}$ Corresponding author: gerco777@yahoo.com
}

\begin{abstract}
A gall is the result of complex interactions between a gall inducing-insect and its host plant. Certain groups of insects have the ability to induce a new structure, a gall, on plant organs by altering the normal growth of the host involved plant organ. The gall usually provides shelter and nutrients, in addition to protection against adverse environmental conditions and natural enemies to the inducing insect and its offspring. The ecological uniqueness of a gall is that it allows the inducing-insect to complete their life cycles. In this study, we have described the structures of different stages of growth of a gall induced by Amphibolips michoacaensis on the buds of leaves on Quercus castanea (Fagaceae) to know the subcellular changes during development. The gall consist of various layers such as a nutritive tissue, a lignified sheath, a spongy layer and an outermost epidermis around a centrally located larval chamber. The nutritive cell of the larval chamber show nuclear and nucleolar hypertrophy in the early phases of growth. The granular profile of the nucleolus suggests an active synthesis of ribosomes indicating an accelerated protein synthesis in these cells. During early stages of growth, the cells of the spongy layers within galls are nucleate and nucleolate and include amyloplasts, and the cytoplasm is less abundant. During later growth stages, the spongy cells are enucleate and enucleolate. Chloroplasts occur in the epidermal cells during early stages of growth, indicating that galls are photosynthetically active in early stages of growth. During intermediate stages of growth, a gradual loss of cellular components occurs commencing in the epidermal cells and progressing towards the nutritive cells.
\end{abstract}

Key words: Amphibolips michoacaensis, Cynipidae, gall morphology, Hymenoptera, Quercus castanea

Resumen: La formación de una agalla es el resultado de una compleja interacción entre el insecto inductor de agallas y su planta hospedera. Ciertos grupos de insectos tienen la habilidad de inducir una nueva estructura, la agalla, sobre los órganos de las plantas alterando el crecimiento normal del órgano de la planta involucrado. Las agallas usualmente proveen refugio y nutrientes, además de protección contra condiciones ambientales adversas y enemigos naturales al insecto inductor y a su descendencia. La particularidad ecológica de la agalla es que permite al insecto inductor completar su ciclo de vida. En este estudio, nosotros hemos descrito la estructura de los diferentes estadios de crecimiento de la agalla inducida por Amphibolips michoacaensis sobre brotes de hojas de Quercus castanea Née (Fagaceae) para conocer los cambios subcelulares durante su desarrollo. La agalla consiste de varias capas tales como tejido nutritivo, una capa de células lignificadas, tejido esponjoso y una capa epidérmica externa que rodean a una cámara larval central. Las células del tejido nutritivo de la cámara larval presentan hipertrofia de núcleo y nucléolo en las fases tempranas de crecimiento. El perfil granular del nucléolo sugiere una síntesis activa de ribosomas indicando un incremento en la síntesis de proteínas en estas células. Durante fases tempranas de crecimiento, las células del tejido esponjoso de la agalla son nucleados y nucleolados e incluye amiloplastos y el citoplasma es menos abundante. Durante las fases tardías del crecimiento, las células del tejido esponjoso son enucleados y enucleolados. Los cloroplastos se presentan en las células epidérmicas en las fases tempranas del crecimiento, lo que indica que las agallas son fotosintéticamente activas en estadios tempranos de crecimiento. Durante las fases intermedias de crecimiento se observa una pérdida gradual de los componentes celulares que comienza en las células de la epidermis y avanzan hasta las células nutritivas.

Palabras clave: Amphibolips michoacaensis, Cynipidae, Hymenoptera, Morfología de agallas, Quercus castanea 
A pproximately 13,000 species of insects belonging to Thysanoptera, Hemiptera, Coleoptera, Lepidoptera and Hymenoptera are known today as gall inducing agents (Dreger-Jauffret and Shorthouse, 1992; Raman et al., 2005). Species of the Cynipoidea (Hymenoptera) induce complex and diversified galls on various plants (Ronquist, 1995, 1999). The Cynipidae are unique because a majority of their species recognized under Aylacini, Diplolepidini, Eschatocerini, Pediaspidini and Cynipini, are specialist plant feeders and they induce galls and only those of the Syndergini are associated with gall-inducing Cynipidae (Ronquist, 1994). A majority of the Cynipidae are associated with Fagaceae and particularly with Quercus (Ronquist and Liljeblad, 2001; Csoka et al., 2005).

Gall-inducing insects are specialist plant feeders and many of them remaining tied to specific plant. The gall is a product of the interspecific association of the plant with the insect, which develops a specific novel structure in response of the insect stimulus (Weis and Abrahamson, 1986; Raman, 2007, 2011). Gall-inducing insects actively manipulate the host plant to induce a structure that provides nutrition to their larvae and protection against adverse environmental conditions and natural enemies (Price et al., 1987; Stone and Schönrogge, 2003). The galls generated by the Cynipidae are the most diverse and structurally complex and they are considered the most evolved galls produced by insects (Nieves-Aldrey, 1998; Raman et al., 2005; Csóka et al. 2005). The galls induced by the Cynipidae comprise multiple and highly differentiated cell layers. The nutritive tissue and lignified sheath enveloping the larva form the "inner gall" and the cortical tissue the "outer gall" (Bronner, 1977). The internal gall size is consistant while the external gall usually varies according to species (Nieves-Aldrey, 1998).

Development of a gall can be seen to include three phases: initiation, growth and maturation (Maresquelle and Mayer, 1965). The gall development starts with the wasp laying eggs in the meristematic tissue of the host plants (Bronner, 1973; Rey, 1992). The plant usually responds with necrosis of cells immediately beneath and around the egg, whereas the adjacent cell layers below and around begin to proliferate. During the growth phase, the cells surrounding the larva turn hypertrophied and hyperplasied, both of which are the most visible responses in gall growth process (Meyer and Maresquelle, 1983). The cells ligning the larval chamber are differentiated as nutritive cells, feeding the growing larvae (Bronner, 1992; Rey, 1992; Brooks and Shorthouse, 1997). The criticality of the developing cynipid larva for the growth and maturation of the gall has been demonstrated: the gall ceases to grow, should the larvae die prematurely (Rey, 1992; Brooks and Shorthouse, 1997; Nieves-Aldrey, 2001). Finally, the maturation phase is characterized by a decrease in cell division activity, most of the gall tissues turn lignified as the larva matures and pupates. The gall eventually desiccates.
Although the overall morphology of cynipid galls may vary, the patterns of the internal tissues layers of the gall are similar in the know galls induced by the Cynipidae, with an outer cortical parenchyma and an inner cavity that contains one to many larval chambers. Each larval chamber is usually encapsulates by a layer of sclerenchyma. Lining the sclerenchyma is the inner gall composed of nutritive parenchyma cells that accumulate lipids, sugars and amino acids (Bronner, 1992; Harper et al., 2004). Starch concentration increases away from the larval chambers while enzymes, lipids and sugar concentration increase towards the larval chambers (Bronner, 1992). All Cynipidae generate this essential nutritive tissue that serves as a source of nourishment for the larva (Rey, 1992). Bronner (1992) reports specific characteristics for inner nutritive cells such as enlarged nucleus and nucleolus, fragmented vacuole, low content of starch and high contents of lipids and proteins.

About $80 \%$ of all the Cynipidae galls form on oak (Quercus) and rose (Rosa) (Ronquist and Liljeblad, 2001; Harper et al., 2004). The majority of the few studies about Cynipidae galls have been made in roses (LeBlanc and Lacroix, 2001; Leggo and Shorthouse, 2006), and one or two about the internal structure of galls induced by cynipid on Quercus; the knopper galls on acorns of $Q$. robur induced by Andricus quercuscalicis and "Oak Apple Gall" in buds of the English oak Q. robur by Biorhiza pallida (Harper et al., 2004).

However, there are no reports of ultrastructural studies in Quercus galls induced by the Cynipidae in Mexico, with approximately 160 species; Mexico is one of the centers of species diversification of genus Quercus (Nixon, 1993). In this study, we described the morphological and anatomical characteristics in different stages of growth of the bud gall induced by Amphibolips michoacaensis on Quercus castanea an endemic species with a wide distribution in Mexico. We compared the cell structure of different stages of growth of galls using electron micrographs of the tissues to know the changes involved in the different layers during the development of the gall wasp.

\section{Material and methods}

Collection of specimens. Galls of Amphibolips michoacaensis Nieves-Aldrey \& Maldonado (Cynipidae) were collected in April-May in 2011 and 2012 on trees of Quercus castanea in central Mexico (1966'17.5' N; $101^{\circ} 16^{\prime}$ $\left.70.2^{\prime \prime} \mathrm{W}\right)$. Galls of different sizes that contained larvae were sampled and measured their diameter, smalls (7 mm diameter), mediums (14-24 mm diameter) and big (36-56 $\mathrm{mm}$ diameter) $(n=80)$. The collected galls were dissected and the tissue of larval chamber, spongy tissue and epidermis were taken for further analysis. Amphibolips michoacaensis is a new species described recently from galls from $Q$. castanea (Nieves-Aldrey et al., 2012). 
Electron microscopy. Tissues were prepared following the protocols described in Jiménez-García and Segura-Valdéz (2004). Briefly, tissues were fixed with $4 \%$ paraformaldehyde plus $6 \%$ glutaraldehyde for $24 \mathrm{~h}$ at room temperature $30{ }^{\circ} \mathrm{C}$. They were then postfixed with $1 \%$ osmium tetroxide for $3 \mathrm{~h}$ and dehydrated with a series of graded ethanol and propylene oxide. Embedding was performed with epoxy resin at $60{ }^{\circ} \mathrm{C}$ for $16 \mathrm{~h}$. Thin sections $250-350 \mathrm{~nm}$, were placed on copper grids, stain with $3 \%$ toluidine blue and covered with Formvar. Sections were contrasted with $5 \%$ uranyl acetate and $0.5 \%$ lead citrate. Grids were observed with a transmission electron microscope (JEOL 1010, JEOL, Peabody, MA) working at $80 \mathrm{kV}$. Images were obtained with a charge-coupled device camera coupled to the microscope.

\section{Results}

Amphibolips michoacaensis induced galls in the buds of Quercus castanea. The spherical galls measured up to 60 $\mathrm{mm}$ of diameter; they are soft to human feel and spongy and green during early stages and turns brown on maturation (Figure 1A, B). The gall induced by A. michoacaensis includes a centrally located single larval chamber occupied by one larva (Figure 1C). Three layers of tissue occur in the galls induced by A. michoacaensis: the nutritive, the spongy and the epidermal cells.

The nutritive cells in growing galls of $6 \mathrm{~mm}$ of diameter showed a centrally located large vacuole, with a few amyloplasts in the cytoplasm (Figures 2A, 3A) and hypertrophy of nucleus and nucleolus (Figures $2 \mathrm{~A}, 3 \mathrm{~B}, \mathrm{C}$ ). The nucleolus appears granular (Figure 4B). In the cytoplasm, the endoplasmic reticulum and many ribosomes were present (Figures 4A, C). In the cells of spongy tissue, the number of amyloplasts were more than that were evident in the nutritive cells (Figures 2B, 3D) and the structure of nucleus and nucleolus present a certain amount of degradation in their structures compared with those of nutritive cells (Fig- ures $3 \mathrm{E}, \mathrm{F})$. Changes in nucleus morphology were visible: a segregated nucleus, less compact and less dense is markedly reduced compared with nutritive cells while central nucleolus present blanched regions and less dense. The epidermal cells show thickened cell walls, many chloroplasts (Figures 2C, 3G, H) and numerous mitochondria (Figure 3I).

When gall size increases to $14 \mathrm{~mm}$ of diameter, some structural changes were observed in their cell layers. The nutritive cells showed hypertrophy of nucleus and nucleolus, the nucleus appears segregates less dense and less compact, the nucleolus present blanched regions, the morphology the nutritive cells are similar to the spongy cells in galls of $6 \mathrm{~mm}$ of diameter (Figure 5A). The number of amyloplasts increased in nutritive cells (Figure 5A), than in previous sizes (6 $\mathrm{mm}$ in diameter) (Figure 3A), and large vacuole fragmented occurred (Figures 2D, 5A). The cells of spongy tissue had a few amyoplasts, appear cytoplasmic remains, a thickened cell wall, few cells had nucleus and nucleolus and the vacuoles were fragmented (Figures $2 \mathrm{E}, 5 \mathrm{~B}, \mathrm{C}$ ). In the epidermal cells thickened cell walls and few cytoplasmic remains can be observed (Figures 2F, 5D). The epidermal cells did not show chloroplasts compared with the smaller galls that had a large number of chloroplasts (Figure 3H); only thickened cell walls and few cytoplasmic remains can be observed (Figures 2F, 5D).

Some nutritive cells in galls of $24 \mathrm{~mm}$ of diameter showed a gradual degradation process of nucleus and nucleolus, while in other cells the nucleus and nucleolus remained intact in structure with a prominent nuclear envelope (Figures 6A-C). In some nutritive cells amyloplasts were evident (Figure 6B). The vacuoles of nutritive cells were fragmented and autophagic vacuoles were apparent (Figures 6C).

In the spongy tissue, cells with large vacuoles and cells with fragmented vacuoles were present (Figure 6D, E), the cell walls were thick and autophagic vacuoles were apparent (Figure 6E) and cytoplasmic debris were present in some cells with greater levels than the others (Figure 6E,
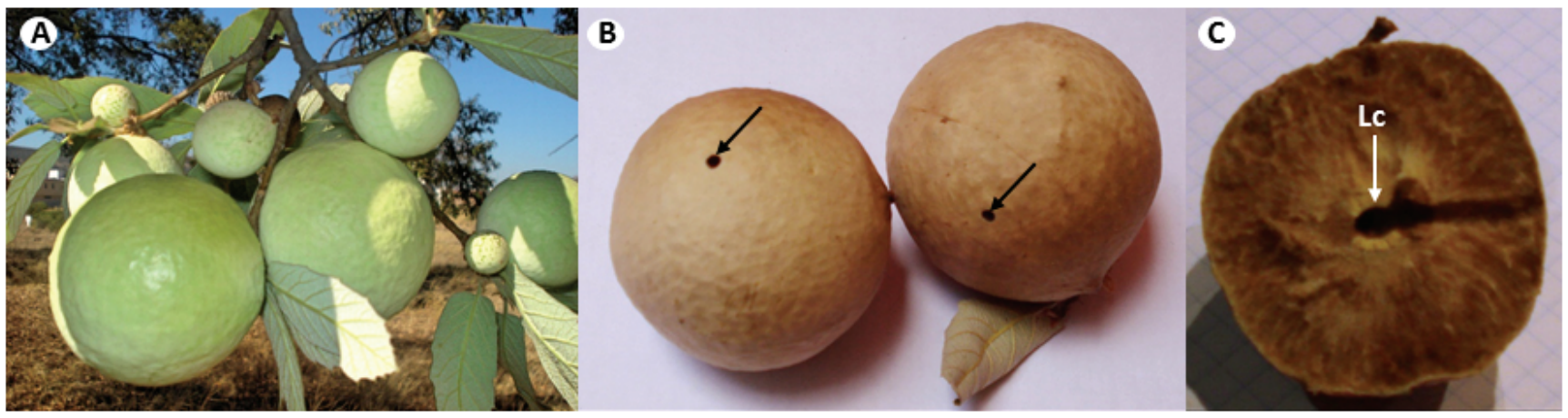

Figure 1. Galls induced by Amphibolips michoacaensis on Quercus castanea. A Galls in different stages of growth in the tree, the galls are smooth and green light in color. B Mature galls, the growth stop and the gall has a brown color and hard tissue; in these galls, the holes made by the insects from inside to leave the gall after a complete development can be observed (arrows). C Cross-section of mature gall, the single larval chamber (Lc) in the center of the gall surrounded by sclerenchyma lignified cells (light brown sheath) and the tunnel made by the insect can be observed. 


\section{Cross-section of gall induced by Amphibolips michoacaensis}

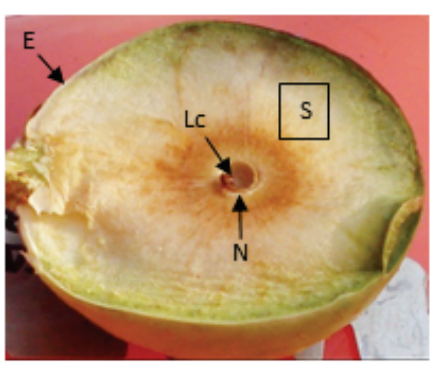

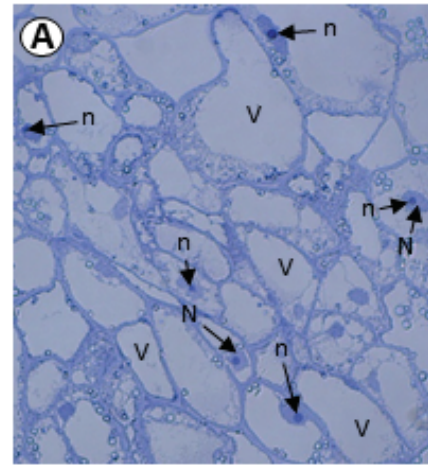
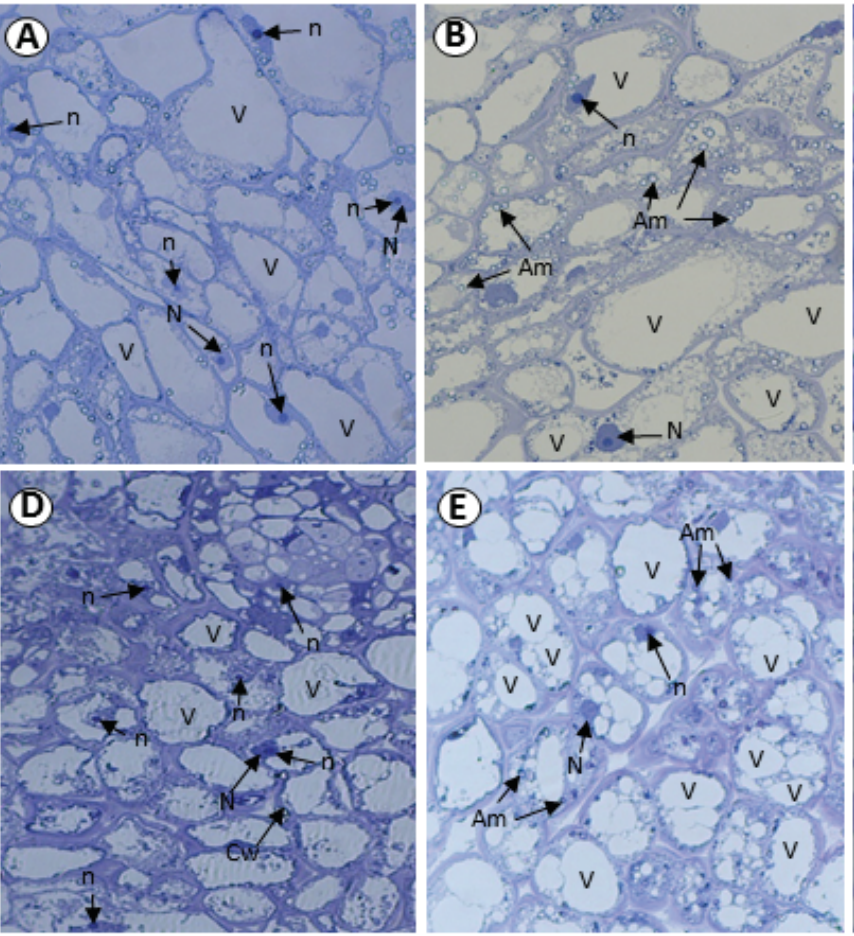
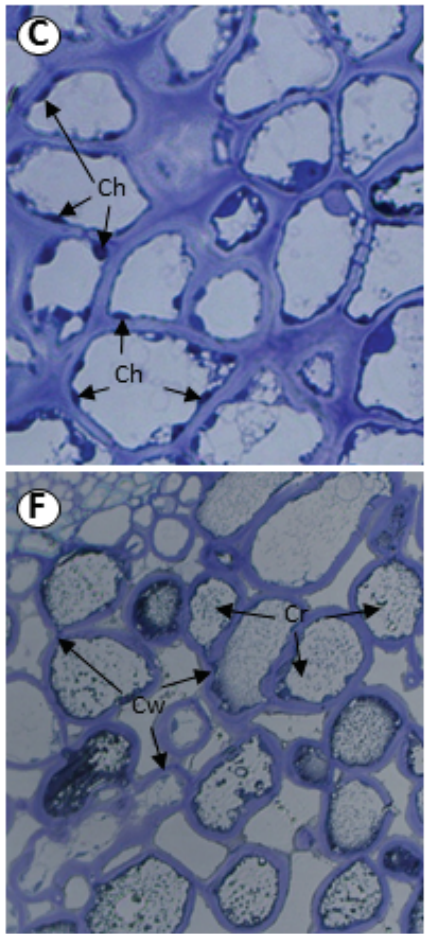

Figure 2. Cross-section of gall induced by Amphibolips michoacaensis; single larval chamber (Lc), nutritive (N), spongy (S) and epidermal (E) cells (color photo at the left). A-C Light micrographs of the different layers in gall of $6 \mathrm{~mm}$ in diameter. A Nutritive cells present hypertrophied nucleus (N) and nucleolus (n) and big central vacuole (V). B Spongy cells present numerous amyloplasts (Am). C Epidermal cells show numerous chloroplasts (Ch). D-F Light micrographs of the different layers in gall of 14 mm in diameter. D Nutritive cells show hypertrophied nucleus $(\mathrm{N})$ and nucleolus (n). E Spongy cells present fragmented vacuoles (V), few cells present nucleus (N) and nucleolus (n). F Epidermal cells had only cytoplasmic remains $(\mathrm{Cr})$ and thickened cell walls $(\mathrm{Cw})$.

F). The most epidermal cells include cytoplasmic debris (Figures 6G, H), whereas other cell were empty (Figure $6 \mathrm{I})$. Both spongy and epidermal cell layers bore thickened cell walls.

The nutritive cells of galls of $36 \mathrm{~mm}$ of diameter rarely include a nucleus and a nucleolus (Figure 7A) and the number of autophagic vacuoles and the content of cytoplasmic remains increased (Figure 7B) compared with the nutritive cells in galls of $24 \mathrm{~mm}$ of diameter (Figure 6C), resembling more to the cells of spongy tissue of galls of $24 \mathrm{~mm}$ of diameter (Figure 6D). There are a few spongy cells with cytoplasmic remains and most of them kept the cell membrane (Figures 7C, D). The epidermal cells were vacant (Figure $7 \mathrm{E})$. The morphology of cells in the spongy tissue and epidermal cells were nearly identical at this stage.

Nutritive cells of galls of $56 \mathrm{~mm}$ of diameter showed few cytoplasmic remnants (Figures 8A, B) similar to cells of spongy tissue in galls of $36 \mathrm{~mm}$ in diameter (Figure 7C). Most of the spongy cells were empty, cells had lignified walls and few cells still included cytoplasmic remains (Figures $8 \mathrm{C}, \mathrm{D}$ ). Epidermal cells were empty (Figures 8E, F). In this gall size, there was no real differences between the three different layers of cells that form the gall; nutritive, spongy and epidermal cells.

\section{Discussion}

The present study shows that the structure of gall induced by Amphibolips michoacaensis in different stages of growth is similar to galls induced by others Cynipidae such as hypertrophied nucleus and nucleolus and abundance of ribosomes in nutritive cells (Rothfritsch, 1974; Bronner, 1992; LeBlanc and Lacroix, 2001; Leggo and Shorthouse, 2006).

Bronner (1992) reported numerous plastids and mitochondrias in the nutritive cells of the Cynipidae galls, whereas in the galls induced by Amphibolips michoacaensis both mitochondria and chloroplasts occurred in epidermal cells of galls during early stages of growth. In galls induced by Diplolepis rosaefolii (Cynipidae) on leaves of Rosa virginiana, fragmented vacuoles occur in cells located at the periphery of nutritive tissue but they are either reduced or absent in cells closet to the larval chamber (LeBlanc and Lacroix, 2001). In galls induced by A. michoacaensis, the cells of nutritive and spongy tissues present large vacuoles during early stages of growth, whereas during later stages of growth they appear fragmented until their disappearance finally. In galls induces by the Cynipidae, Andricus quercuscalicis and Biorhiza pallida on Quercus robur, the immediate layers surrounding the larva had enlarged cells filled 

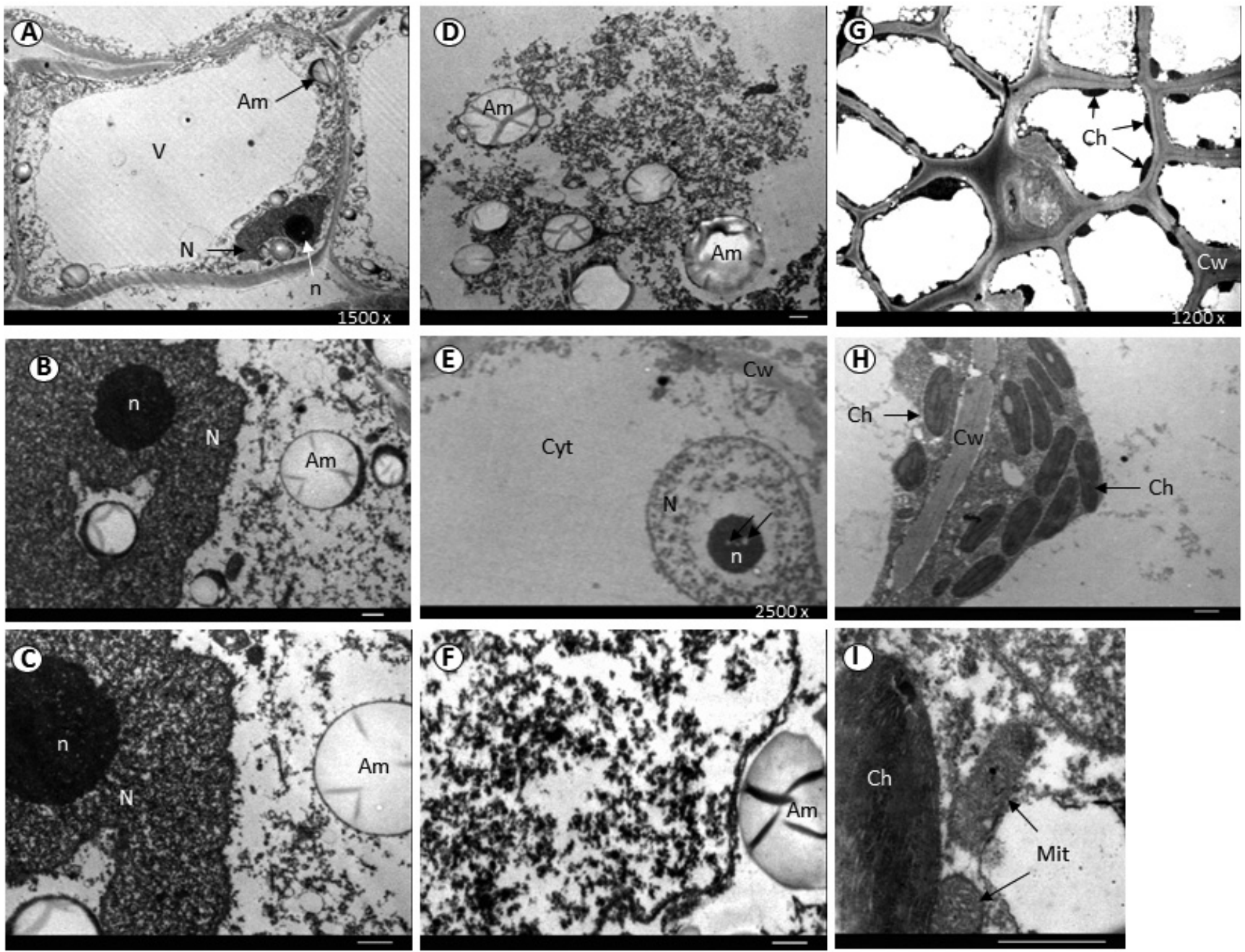

Figure 3. Ultrastructural morphology of galls with $6 \mathrm{~mm}$ in diameter. A-C Cells in nutritive tissue. The nucleus (N) and nucleolus (n) are hypertrophied, the cytoplasm contains few amyloplasts (Am) and a big vacuole (V). D-F Cells in spongy tissue. The internal organization of the nucleus (n) is lost. An increment in the number of amyloplasts (Am) is observed in cytosol (Cyt). G-H Cells in epidermal tissue containing mitochondria (Mit) and numerous chloroplasts $(\mathrm{Ch})(\mathrm{bar}=1 \mu \mathrm{m})$.
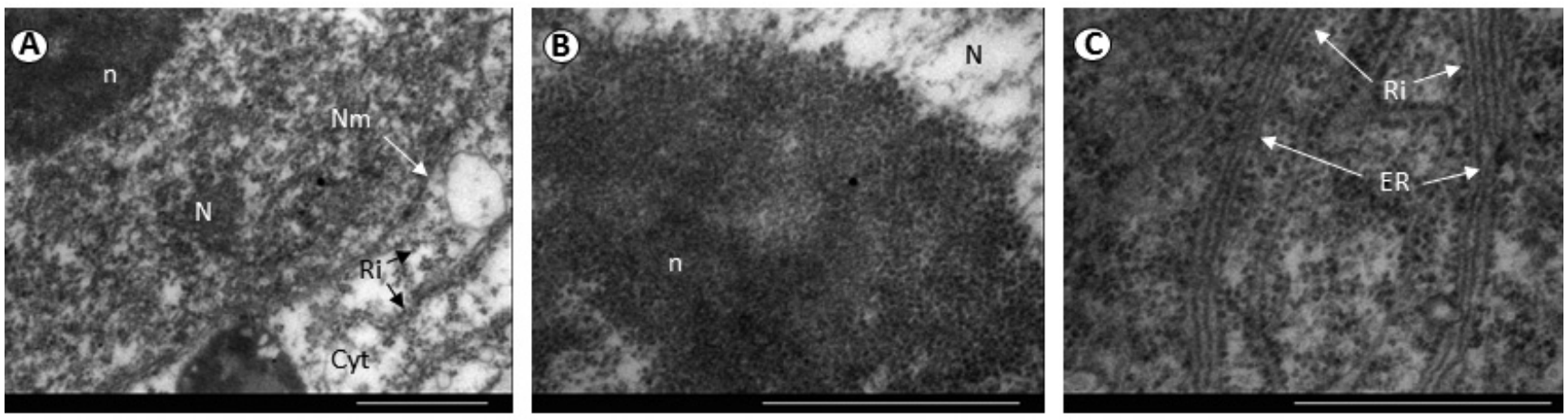

Figure 4. A-C Ultrastructural morphology of nutritive cells in galls of $6 \mathrm{~mm}$ in diameter. The nucleus (N) and nucleolus (n) are dense; the nucleolus has a granular structure and the cytoplasm $(\mathrm{Cyt})$ present rough endoplasmic reticulum $(\mathrm{ER})$ and ribosomes $(\mathrm{Ri})(\mathrm{bar}=1 \mu \mathrm{m})$. 

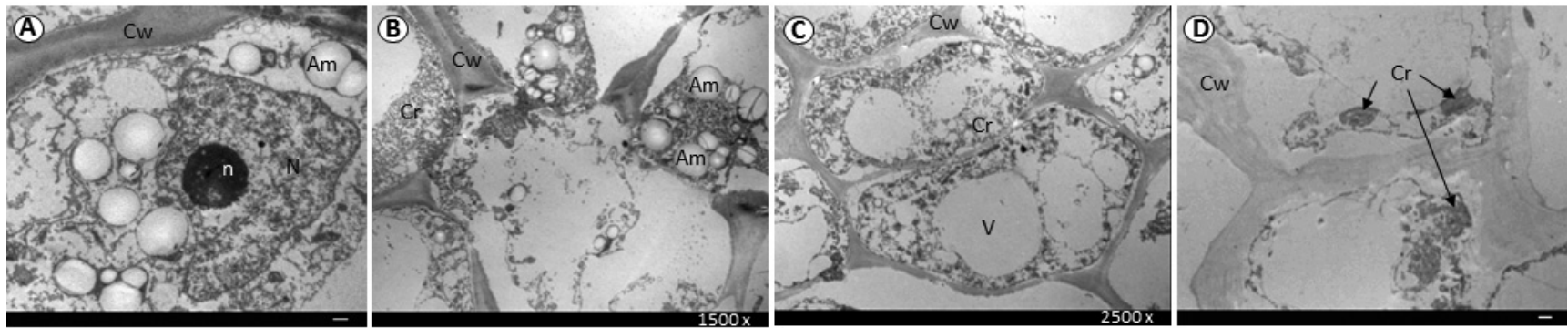

Figure 5. Ultrastructural morphology of galls of $14 \mathrm{~mm}$ in diameter. A Cells in nutritive tissue surrounding the larval chamber present engrossed cell walls $(\mathrm{Cw})$, abundant amyloplasts $(\mathrm{Am})$, hypertrophied nucleolus (n) and cytoplasm (Cyt). B-C Spongy tissue cells, single or some vacuoles (V) per cell and less amyloplasts (Am) than proximal cells to the chamber. D Cells in epidermal tissue show cytoplasmic remains $(\mathrm{Cr})$ and engrossed cell wall $(\mathrm{Cw})(\mathrm{bar}=1 \mu \mathrm{m})$.
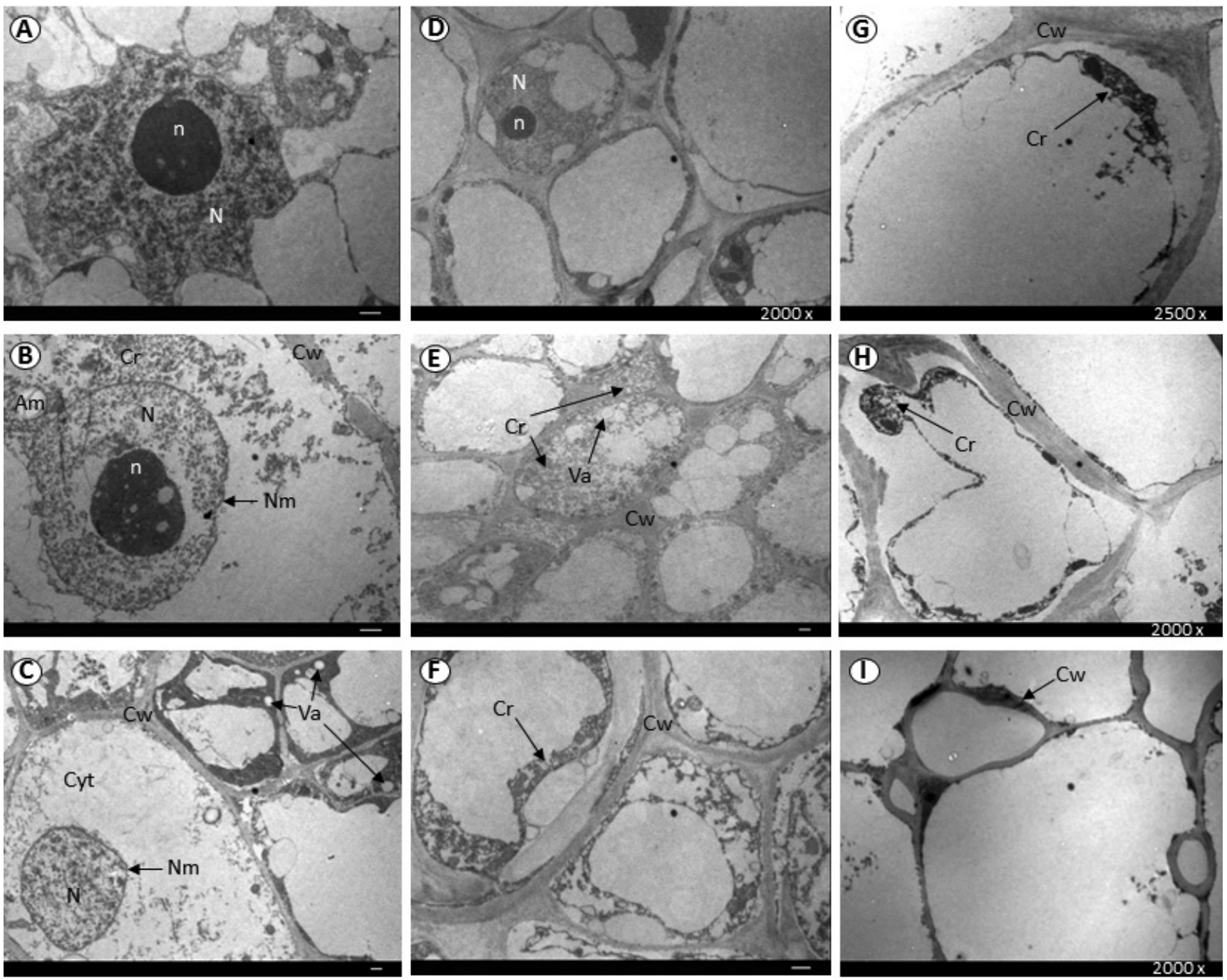

Figure 6. Ultrastructural morphology of galls of $24 \mathrm{~mm}$ in diameter. A-C Cells of nutritive tissue present hypertrophied nucleus (N) and nucleolus (n) with loss of structure, present nuclear membrane (Nm) and in some cells appear autophagic vacuole (Va). D-F Cells of spongy tissue show big and fragmented vacuoles (V), autophagic vacuoles (Va) with poor cytoplasmic content (Cyt) and occasionally cells with nucleus $(\mathrm{N})$ and nucleolus (n). G-I Epidermal cells show membranes disjoined to cell wall (Cw), remains cytoplasmic (Cr) and engrossed cell wall (bar $=1 \mu \mathrm{m})$. 

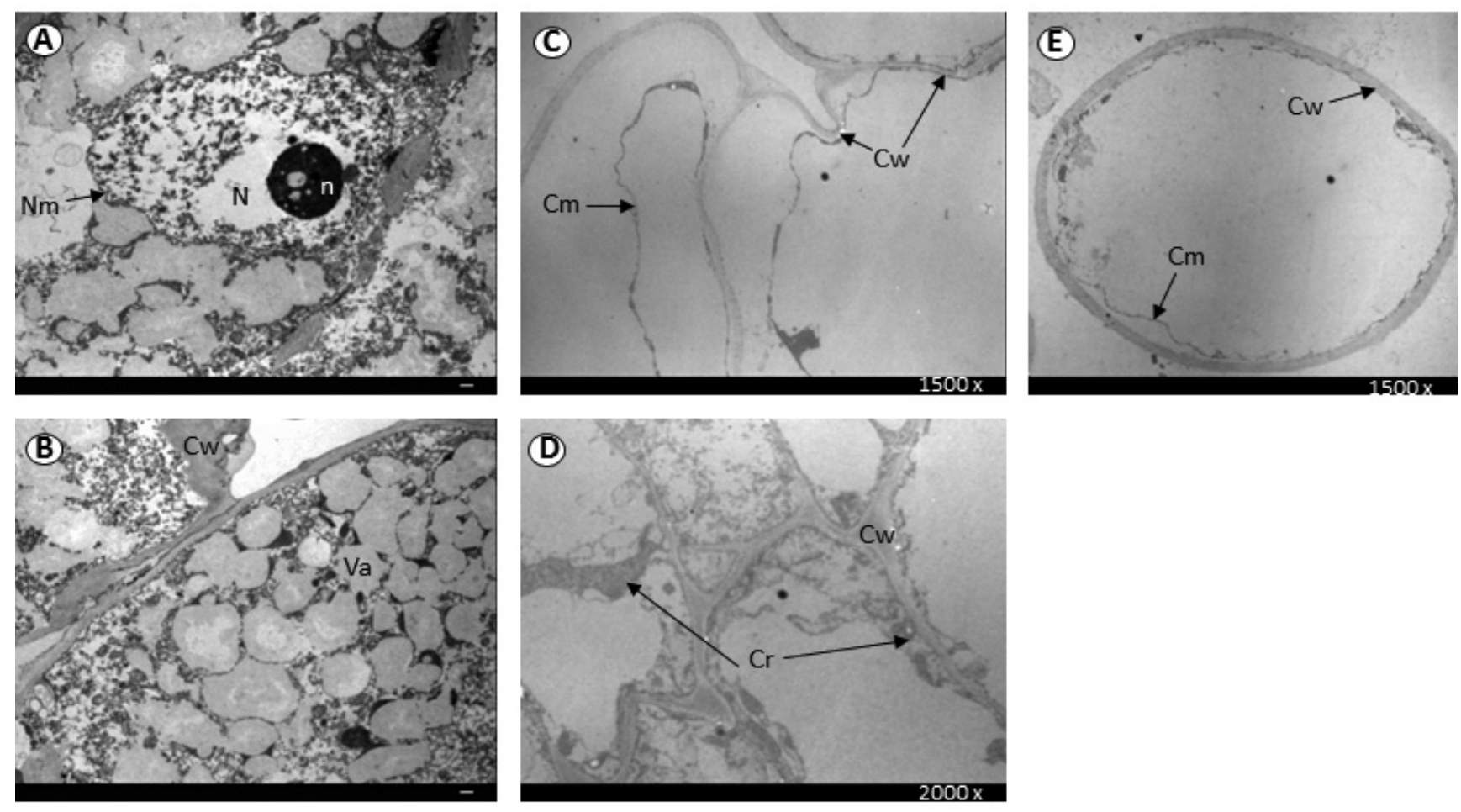

Figure 7. Ultrastructural morphology of galls of $36 \mathrm{~mm}$ in diameter. A-B Nutritive cells present a great amount of autophagic vacuoles (Va) and few cells with nucleus $(\mathrm{N})$ or nucleolus (n). C-D Spongy cells present cytoplasmic remains $(\mathrm{Cr})$ and thickened cell wall $(\mathrm{Cw})$. E The epidermal cells present cell membrane $(\mathrm{Cm})$ and thickened cell wall $(\mathrm{Cw})(\mathrm{bar}=1 \mu \mathrm{m})$.
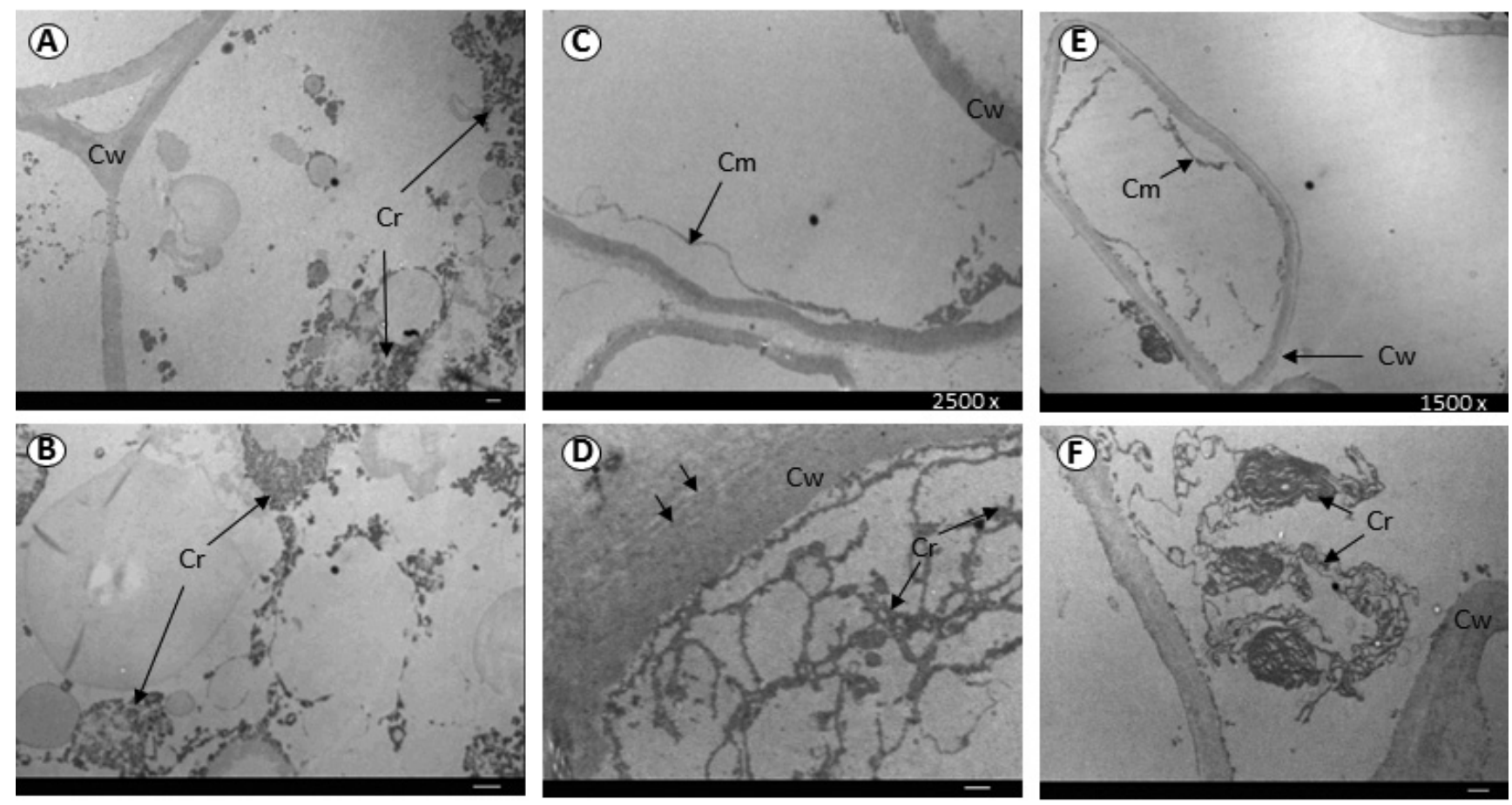

Figure 8. Ultrastructural morphology of gall of $56 \mathrm{~mm}$ in diameter galls. A-B Nutritive cells present few cytoplasmic remains (Cr). C-D Spongy tissue cells present cell wall $(\mathrm{Cw})$ and cytoplasmic remains $(\mathrm{Cr})$. E-F Epidermal cells $($ bar $=1 \mu \mathrm{m})$. 
with lipidic materials with enlarged nuclei and nucleoli (Harper et al., 2004), agree with the found in nutritive cells in the galls induced by A. muchoacaensis. The presence of chloroplasts in epidermal cells suggest photosynthetic activity during early stages of gall growth.

The most impressive events of growth and metabolic process during gall development, such as proteins synthesis and generation of energy materials, occur during early stages of growth. The nucleolus, where the ribosomal subunits are assembled, appears granular (Hernández-Verdún, 2006). The nucleolar hypertrophy and the increment of ribosome biogenesis in plant cells stimulate induce proliferation as a result of greater biosynthetic demand (Montanaro et al., 2008). In later stages of growth, the total absorption of this energy, the assimilation of proteins and the absorption of all cellular components occurred; these processes occurred from outer to inner cell layers. All these processes finished with a thickened cell wall maintaining the shape and hardness of the galls that provide protection to the wasp during the pupal stage (Stone et al., 2002).

The larvae of gall-inducing Cynipidae can alter the physiology of host tissues (Leggo and Shorthouse, 2006), the structure and anatomy of layers of gall is related with the stage of development of insect inside of this structure. The changes in the nutritive, spongy and epidermal cells show the specific requirements of insect in growth and metamorphosis.

A complex interaction between insects and plants manifests in galls induced by insects, among which the most diversified group is the Cynipidae (Stone and Schönrogge, 2003). Galls provide food, shelter and protection to the larvae of the Cynipidae enabling them to complete their life cycles. In this study, we explain the differentiation and structure of cells that make the galls induced by Amphibolips michoacaensis on Quercus castanea leaves.

\section{Acknowledgments}

Authors thank to A. Raman and two anonymous reviewers that improved earlier drafts of this manuscript. PHS acknowledges financial support from CONACYT (scholarship no. 43987) and the Posgrado en Ciencias Biológicas (graduate program) of the Universidad Nacional Autónoma de Mexico (UNAM). This project was supported by SEMARNAT-CONACYT grants 2004-C01-97, 200623728, CONACYT 38550-V, 2007-80493 and DGAPAUNAM grants IN209108, IN229803 and IV201015.

\section{Literature Cited}

Bronner R. 1973. Propriétés lytiques des œufs de Biorhiza pallida Ol. OO'. Comptes Rendus de l'Académia des Sciences Paris 276:189-192.

Bronner R. 1977. Contributions à l'étude histochimique des tissus nourriciers des zoocécidies. Marcellia 40:1-134.
Bronner R. 1992. The role of nutritive cells in the nutrition of cynipids and cecidomyiids. In: Shorthouse J.D. and Rohfritsch O. Eds. Biology of Insect-Induced Galls, pp. 118-140. Oxford University Press, Oxford.

Brooks S.E. and Shorthouse J.D. 1997. Biology of the rose stem galler Diplolepis nodulosa (Hymenoptera: Cinipidae) and its associated component community in central Ontario. The $\mathrm{Ca}$ nadian Entomologist 129:1121-1140.

Csóka G., Stone G.N. and Melika G. 2005. Biology, ecology and evolution of gall-inducing Cynipidae. In: Raman A., Schaefer C.W. and Withers T.M. Eds. Biology, Ecology and Evolution of Gall-Inducing Arthropods, Volume 2 pp. 573-642. Science Publishers, New Hampshire.

Dreger-Jauffret F. and Shorthouse J.D. 1992. Diversity of gall-inducing insects and their galls. In: Shorthouse J.D. and Rohfritsch O. Eds. Biology of Insect-Induced Galls, pp. 8-33. Oxford University Press, Oxford.

Harper L.J., Schönrogge K., Lim K.Y., Francis P. and Lichtenstein C.P. 2004. Cynipid galls: insect-induced modifications of plant development create novel plant organs. Plant Cell and Environment 27:327-335.

Hernández-Verdún D. 2006. Nucleolus: from structure to dynamics. Histochemistry and Cell Biology 125:127-137.

Jiménez-García L.F. and Segura-Valdéz M.L. 2004. Visualizing nuclear structure in situ by atomic forcé microscopy. Methods in Molecular Biology 242:191-199.

LeBlanc D.A. and Lacroix C.R. 2001. Developmental potential of galls induced by Diplolepis rosaefolii (Hymenoptera: Cynipidae) on the leaves of Rosa virginiana and influence of Periclistus species on the Diplolepis rosaefolii galls. International Journal of Plant Sciences 162:29-46.

Leggo J.J. and Shorthouse J.D. 2006. Development of stem galls induced by Diplolepis triforma (Hymenoptera: Cynipidae) on Rosa aciculais (Rosaceae). The Canadian Entomologist 138:661-680.

Maresquelle H.J. and Meyer J. 1965. Physiologie et morphogenèse des galles d'origine animale (zoocécides). In: Ruhland W., Ashby E., Bonner J., Geiger-Huber M., James W.O., Lang A., Müller D. and Stålfelt M.G. Eds. Handbuch der Pflanzenphysiologie, Band XV: Differenzierung und Entwicklung, Teil 2. Pp. 280-329. Springer-Verlang, Berlin.

Meyer J. and Maresquelle H.J. 1983. Anatomie des Galles. Gebruder Borntraeger. Berlin.

Montanaro L., Treté D. and Derenzi M. 2008. Nucleolus, ribosomes and cancer. The American Journal of Pathology 173:301-310.

Nieves-Aldrey J.L. 1998. Insectos que inducen la formación de agallas en las plantas: una fascinante interacción ecológica y evolutiva. Boletín S.E.A. 23:3-12.

Nieves-Aldrey J.L. 2001. Hymenoptera Cynipidae. Fauna Iberica Vol. 16. Consejo Superior de Investigaciones Científicas, Madrid.

Nieves-Aldrey J.L., Pascual E., Maldonado-López Y., Medianero E. and Oyama K. 2012. Revision of the Amphibolips species of Mexico excluding the "niger complex" Kinsey (Hymenoptera: Cynipidae), with description of seven new species. Zootaxa 3545:1-40.

Nixon K.C. 1993. The genus Quercus in Mexico. In: Ramammoorthy T.P., Bye R., Lot A. and Fa J. Eds. Biological Diversity of Mexico: Origins and Distribution, pp 447-458. Oxford University Press, Oxford. 
Price P.W., Fernandes G.W. and Waring G.L. 1987. Adaptive nature of insect galls. Environmental Entomology 16:15-24.

Raman A. 2007. Insect-induced plant galls of India: unresolved questions. Current Science 92:748-757.

Raman A. 2011. Morphogenesis of insect-induced plant galls: facts and questions. Flora 206:517-533.

Raman A., Schaefer C.W. and Withers T.M. Eds. 2005. Biology, Ecology, and Evolution of Gall-Inducing Arthropods. Science Publishers, New Hampshire.

Rey L.A. 1992. Developmental morphology of two types of hymenopterous galls. In: Shorthouse J.D. and Rohfritsch O. Eds. Biology of Insect-Induced Galls, pp. 87-101. Oxford University Press, Oxford.

Rohfritsch O. 1974. Infrastructure du tissu nourricier de la galle de 1'Aulax glechomae L. sur Glechoma hederácea L. Protoplasma 81: 205-230.

Ronquist F. 1994. Evolution of parasitism among closely related species: phylogenetic relationships and the origin of inquilinism in gall wasp (Hymenoptera, Cynipidae). Evolution 48:241-266.

Ronquist F. 1995. Phylogeny and early evolution of the Cynipoidea (Hymenoptera). Systematic Entomology 20:309-335.

Ronquist F. 1999. Phylogeny, classification and evolution of the Cynipoidea. Zoologica Scripta 28:139-164.

Ronquist F. and Liljeblad J. 2001. Evolution of the gall wasp-host plant association. Evolution 55:2503-2522.

Stone G.N. and Schönrogge K. 2003. The adaptive significance of insect gall morphology. Trends in Ecology and Evolution 18:512-522.

Stone G.N., Schönrogge K., Atkinson R.J., Bellido D. and Pujade-Villar J. 2002. The population biology of oak gall wasps (Hymenoptera: Cynipidae). Annual Review of Entomology 47:633-668.

Weis A.E. and Abrahamson W.G. 1986. Evolution of host plant manipulation by gall makers: ecological and genetic factors in the Solidago-Eurosta system. The American Naturalist 127:681-695.

Received: June 17th, 2015

Accepted: July 2nd, 2015 